\title{
Can domoic acid affect escape response in copepods?
}

\author{
Sara Harðardóttir ${ }^{\mathrm{a}, *}$, Bernd Krock ${ }^{\mathrm{b}}$, Sylke Wohlrab ${ }^{\mathrm{b}, \mathrm{c}}$, Uwe John ${ }^{\mathrm{b}, \mathrm{c}}$, Torkel Gissel Nielsen ${ }^{\mathrm{d}}$, \\ Nina Lundholm ${ }^{\mathrm{a}}$ \\ a Natural History Museum of Denmark, University of Copenhagen, Øster Farimagsgade 5, 1307 Copenhagen K Denmark \\ ${ }^{\mathrm{b}}$ Alfred Wegener Institute, Helmholtz Centre for Polar and Marine Research, Am Handelshafen 12, 27570 Bremerhaven, Germany \\ ${ }^{\mathrm{c}}$ Helmholtz Institute for Functional Marine Biodiversity, Ammerländer Heerstraße 231, 23129 Oldenburg, Germany \\ d National Institute of Aquatic Resources, Technical University of Denmark, Building 201 Kemitorvet, Lyngby Campus, 2800 Kgs., Lyngby, Denmark
}

\section{A R T I C L E I N F O}

\section{Keywords:}

Pseudo-nitzschia

Domoic acid

Calanus

Escape jumps

\begin{abstract}
A B S T R A C T
Copepods are important grazers on toxic phytoplankton and serve as vectors for algal toxins up the marine food web. Success of phytoplankton depends among other factors on protection against grazers like copepods, and same way copepod survival and population resilience relies on their ability to escape predators. Little is, however, known about the effect of toxins on the escape response of copepods. In this study we experimentally tested the hypothesis that the neurotoxin domoic acid (DA) produced by the diatom Pseudo-nitzschia affects escape responses of planktonic copepods. We found that the arctic copepods Calanus hyperboreus and C. glacialis reduced their escape response after feeding on a DA-producing diatom. The two species were not affected the same way; $C$. hyperboreus was affected after shorter exposure and less intake of DA. The negative effect on escape response was not related to the amount of DA accumulated in the copepods. Our results suggest that further research on the effects of DA on copepod behavior and DA toxicity mechanisms is required to evaluate the antigrazing function of DA.
\end{abstract}

Predation is a major cause of copepod mortality, and processes that negatively affect the sensory system of copepods or their mobility may affect predation (Kerfoot, 1978; Hirst and Kiørboe, 2002; Almeda et al., 2017; van Someren Gréve et al., 2017). Copepods detect predators by sensing hydromechanical disturbances (Kerfoot, 1978; Haury et al., 1980; Kiørboe and Visser, 1999) and their escape response is a forceful jump away from that stimulus (Ohman, 1988; Fields and Yen, 1997; Wohlrab et al., 2010; Bradley et al., 2013). Hence a successful escape response in copepods requires both detecting the disturbance in the water and the muscle power to perform a jump.

Diatoms of the genera Nitzschia and Pseudo-nitzschia produce a neurotoxin, domoic acid (DA), which can be transferred via copepods to higher food web levels (Leandro et al., 2010a; Tammilehto et al., 2012; D'Agostino et al., 2017) and intoxicate organisms such as seabirds, whales and seals (Fritz et al., 1992; Leandro et al., 2010b; Jensen et al., 2015). Domoic acid can also cause amnesic shellfish poisoning in humans (Quilliam and Wright, 1989; Landsberg, 2002). Presently, two species of Pseudo-nitzschia, P. seriata and P. obtusa, are known to induce DA production in the presence of copepods (Harðardóttir et al., 2015; Tammilehto et al., 2015). Pseudo-nitzschia seriata is known to elevate DA production as a respond to predator cues from various copepods species with high DA levels in correlation to high concentration of predator exoduses (Lundholm et al., 2018). Suggesting that DA production is a chemical defense mechanism against predation. Copepods, one of main grazers of diatoms in marine ecosystems, seem to be resistant to DA, making the role of the grazer-induced DA speculative. Copepod species of Calanus and Acartia are known to feed on toxic Pseudo-nitzschia without any grazing deterrence and they do not select alternative non-toxic prey when given a choice (Windust, 1992; Tester and Douchette, 2001; Maneiro et al., 2005; Leandro et al., 2010a). A single report exists of a changed temporal feeding pattern in Calanus spp. after consumption of DA (Tammilehto et al., 2012). Egg production and hatching is not reduced in Calanus spp. by feeding on toxic Pseudonitzschia (Miesner et al., 2016). Only one report of increased mortality, due to DA has been published until now, for ecologically relevant DA levels (Lundholm et al., 2018).

Domoic acid is an excitatory amino acid and an analogue to glutamate (Wright et al., 1989). Crustaceans use glutamate as a neurotransmitter in both the peripheral and central nervous system (Eckert and Randall, 1983). We hypothesize that DA may interfere with neurotransmission regulation and consequently affect escape responses in copepods. In this study we tested if the escape response is reduced in

\footnotetext{
* Corresponding author.

E-mail address: Sara.Hardardottir@snm.ku.dk (S. Harðardóttir).
} 
Table 1

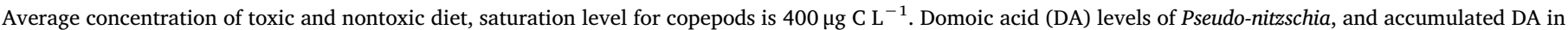

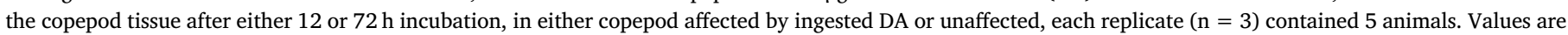
given as mean and standard deviation.

\begin{tabular}{|c|c|c|c|c|c|}
\hline $\begin{array}{l}\text { Copepod Treatment } \\
\text { Time }\end{array}$ & $\begin{array}{l}\text { Start diet concentration: } \\
\left(\mu \mathrm{g} \mathrm{C} \mathrm{L}^{-1}\right)\end{array}$ & $\begin{array}{l}\text { End diet concentration: } \\
\left(\mu \mathrm{g} \mathrm{C} \mathrm{L}^{-1}\right)\end{array}$ & $\begin{array}{l}\text { Start DA content of Pseudo- } \\
\text { nitzschia } \\
\text { (pg DA cell }{ }^{-1} \text { ) }\end{array}$ & $\begin{array}{l}\text { End DA content of Pseudo- } \\
\text { nitzschia } \\
\left(\text { pg DA cell }^{-1}\right)\end{array}$ & $\begin{array}{l}\text { Accumulated DA in copepods unaffected } \\
\text { / affected } \\
\left(\text { ng DA } \mathrm{mgC}^{-1} \text { ) }\right.\end{array}$ \\
\hline \multicolumn{6}{|l|}{ Calanus hyperboreus } \\
\hline \multicolumn{6}{|c|}{ Treatment with toxic Pseudo-nitzschia } \\
\hline $12 \mathrm{~h}:$ & $1628 \pm 602$ & $696 \pm 445$ & $16.3 \pm 5.5$ & $20.9 \pm 5.9$ & $\begin{array}{l}120.7 \pm 47.5 / \\
62.5 \pm 16.5\end{array}$ \\
\hline $72 \mathrm{~h}:$ & $3661 \pm 108$ & $1034 \pm 151$ & $6.6 \pm 0.4$ & $14.4 \pm 2.3$ & $\begin{array}{l}103.1 \pm 87.8 / \\
45.5 \pm 22.2\end{array}$ \\
\hline \multicolumn{6}{|c|}{ Control with non-toxic Thalassiosira } \\
\hline $12 \mathrm{~h}:$ & $2875 \pm 460$ & $1981 \pm 238$ & & & \\
\hline $72 \mathrm{~h}$ & $3300 \pm 841$ & $2620 \pm 445$ & & & \\
\hline \multicolumn{6}{|l|}{ Calanus glacialis } \\
\hline \multicolumn{6}{|c|}{ Treatment with toxic Pseudo-nitzschia } \\
\hline $12 \mathrm{~h}:$ & $1628 \pm 602$ & $762 \pm 130$ & $16.3 \pm 5.5$ & $18.1 \pm 3.4$ & $\begin{array}{l}1047.5 \pm 351 / \\
676.4 \pm 182.4\end{array}$ \\
\hline $72 \mathrm{~h}:$ & $3661 \pm 108$ & $1083 \pm 180$ & $6.6 \pm 0.4$ & $10.5 \pm 1.6$ & $\begin{array}{l}514.6 \pm 192.6 / \\
353.7 \pm 102.5\end{array}$ \\
\hline \multicolumn{6}{|c|}{ Control with non-toxic Thalassiosira } \\
\hline $12 \mathrm{~h}:$ & $2875 \pm 460$ & $2620 \pm 445$ & & & \\
\hline $72 \mathrm{~h}:$ & $3300 \pm 841$ & $1300 \pm 929$ & & & \\
\hline
\end{tabular}

copepods after feeding on toxic Pseudo-nitzschia. Prior to incubations, the animals were starved for $>24 \mathrm{~h}$. The incubations were carried out in the dark at $\sim 4 \mathrm{C}^{\circ}$. Two arctic Calanus copepod species $C$. hyperboreus and C. glacialis, were exposed to diets of either the toxic Pseudo-nitzschia seriata or a non-toxic Thalassiosira gravida for 12 and $72 \mathrm{~h}$ in $5 \mathrm{~L}$ buckets, one bucket per treatment, with saturating food conditions of $>400 \mu \mathrm{g}$ $\mathrm{C} \mathrm{L}^{-1}$, (Hansen et al., 1996). Food concentration was above saturation levels for both diets at the end of the experiment (Table 1). The two diatoms differ in size, shape and carbon content but both diatom species are in the size range that both Calanus species are known to feed on.

A siphon experiment was conducted to trigger escape jumps. From the incubation buckets, single copepods were carefully placed in a petri dish filled with filtered sea water. A pasteur pipette was used to create a hydromechanical signal by placing the tip in the liquid and using the suction to create a this signal, similar to theory in Titelman, (2001) and Kiørboe and Visser (1999), and the set up in Wohlrab et al., (2010). When a copepod showed at least one escape response, by jumping when perceiving the stimuli, it was classified as "unaffected" by DA. Only when copepods did not respond after three stimuli, they were classified as "affected" copepods. Each assay was tested on 100 copepods for each treatment variable; diet, exposure time and copepod species. The data were statistically analyzed by applying a generalized linear model (glm) (McCullagh,1984) to interpret the proportion of success with numerical vector values ( 0 or 1 ). This was done with the statistical package MASS (Venables and Ripley, 2002) using the programme R (R Core Team, 2018) and SigmaPlot (2018).

Domoic acid content in the affected and unaffected copepods was measured in triplicates of five copepods to assess if accumulation of DA explain the changes in escape responses (for method details see suppl. Material).

The species $C$. hyperboreus was affected after incubation with DAproducing Pseudo-nitzschia; the escape responses were reduced from 66 and $60 \%$ in the control treatments to 40 and $37 \%$ after $12 \mathrm{~h}$ and $72 \mathrm{~h}$ of incubation, respectively (Fig. 1, top). In contrast, the escape response of C. glacialis was not affected after $12 \mathrm{~h}$, but after $72 \mathrm{~h}$ a reduction in the escape response became evident, from $67 \%$ in the control to $25 \%$ in the treatment (Fig. 1, bottom). Both diet and exposure time significantly affected escape responses of the copepods (gls, $P<0.0001$ for both variables), and the response of the two species was significantly different (gls, $P<0.05$ ), with a more pronounced response in $C$. glacialis after $72 \mathrm{~h}$. Domoic acid content in the copepods differed between affected or unaffected but the differences were not significantly different (One-Way ANOVA, $P>0.05$ ) (Table 1). Of the two species studied, $C$. glacialis accumulated more DA $\mathrm{mg} \mathrm{C}^{-1}$ than $C$. hyperboreus after both 12 and $72 \mathrm{~h}$ of incubation (t-test, $P<0.05$ ) (Table 1 ). The negative effect of DA was only observed after $72 \mathrm{~h}$ in $C$. glacialis.

Our results suggest that escape responses of both copepod species are affected by ingestion of DA-producing diatoms, however not in the same way. The copepod $C$. hyperboreus is affected both sooner and after having accumulated less DA than $C$. glacialis indicating that $C$. hyperboreus is more vulnerable to the toxin. The feeding strategy of the two species is the same; selective suspension feeders that graze on phytoplankton and heterotrophic protists (Mullin, 1963). The two copepods are different in size (carbon body weight $0.11 \mathrm{mg}$ C for C. glacialis and $1.31 \mathrm{mg} \mathrm{C}$ for C. hyperboreus Swalethorp et al., 2011), have different life strategies (Madsen et al., 2001; Swalethorp et al., 2011), and hence behavior and escape capabilities vary between species which can affect the risk of predation (Almeda et al., 2017). The threshold for an escape response is variable beetween different species of copepods, and between different stages and sex within a single species (Fields \& Yen, 1997; Buskey et al., 2002). There was not a difference between the Calanus species in the control, suggesting they have similar initial response to the stimuli. The amount of accumulated toxins is variable between the time of exposure and affected or unaffected, but this difference is not significant for either species. We used five animals in each replicate but the standard variation is high (Table 1) indicating a large individual variation and may explain the lack of statistical difference.

The results of this study thus indicate a sub-lethal affect. The reduced escape response observed here might be caused by DA interfering with neurotransmission regulation in the copepods as hypothesized above. A parallel mechanism has previously been suggested for saxitoxin production in the dinoflagellate Alexandrium (Wohlrab et al., 2010). The reduction in escape response of copepods will increase copepod mortality by predation and thereby reduce grazing pressure on the toxic diatoms and consequently promote the transfer of DA to higher trophic levels of the food web. In conclusion, the results suggest that DA has a role in the defense mechanism to reduce grazing on toxic diatoms.

\section{Acknowledgements}

We wish to thank the crew on Arctic Station and local hunters in 


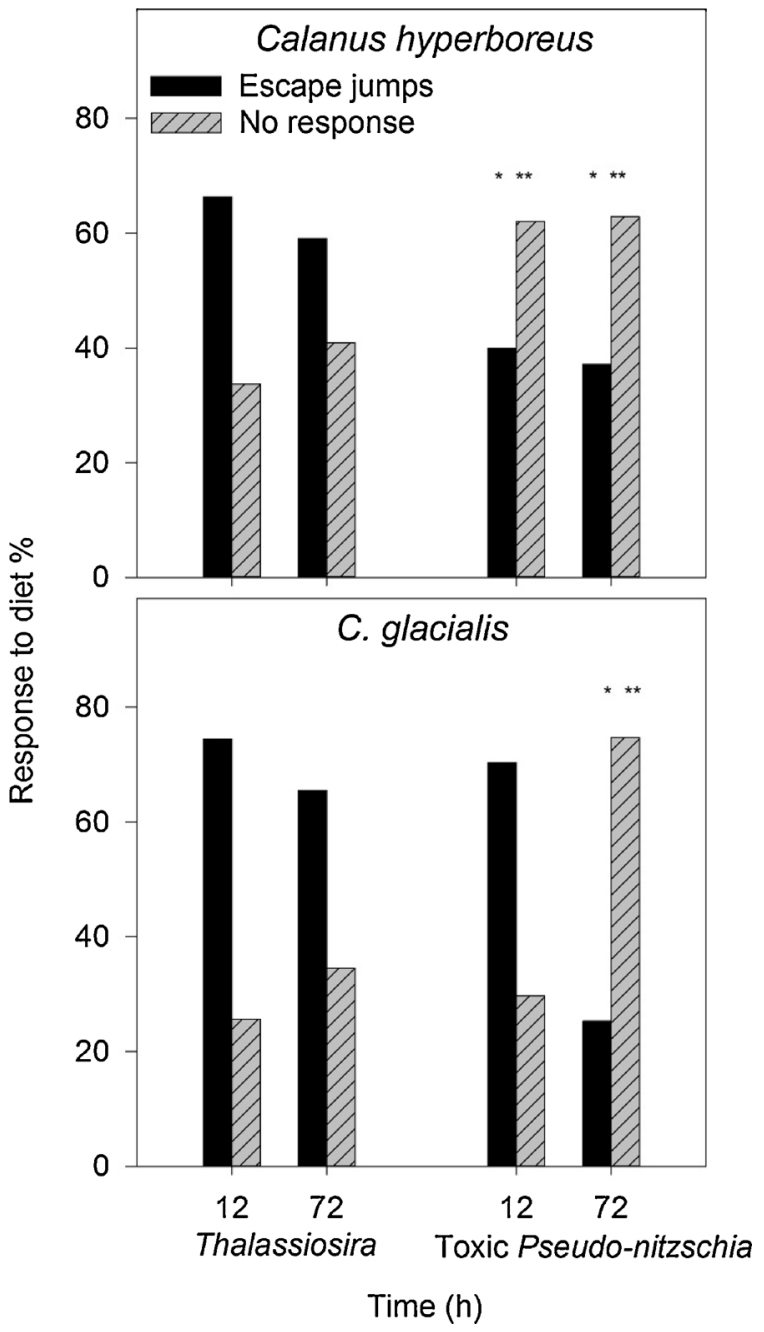

Fig. 1. Copepod escape jumps in Calanus hyperboreus and C. glacialis after feeding on toxic Pseudo-nitzschia seriata or control diet of non-toxic Thalassiosira gravida after 12 or $72 \mathrm{~h} . \mathrm{n}=100$. Each treatment results are given in $\%$ of total. The data was statistically analyzed by applying a generalized linear model and found a difference between the species $p<0.05$ (results not presented), diet and time result presented as $*=$ difference to control and $* *=$ difference over time $p<0.001$ for both.

Qeqertarsuaq. We thank Lumi Haraguchi for valuable help with the statistical analysis and Ditte Marie Hjort for assistance with experiments. The project is funded by Independent Research Fund Denmark, grant DFF-1323-00258 and partially financed by the HelmholtzGemeinschaft Deutscher Forschungszentren through the research programme "Polar regions And Coasts in the changing Earth System" (PACES II) of the Alfred Wegener Institut-Helmholtz Zentrum für Polarund Meeresforschung. [CG]

\section{Appendix A. Supplementary data}

Supplementary material related to this article can be found, in the online version, at doi:https://doi.org/10.1016/j.hal.2018.08.009.

\section{References}

Almeda, R., Greve, H.V., Kiørboe, T., 2017. Behavior is a major determinant of predation risk in zooplankton. Ecosphere 2, 8.

Bradley, C.J., Strickler, J.R., Buskey, E.J., Lenz, P.H., 2013. Swimming and escape behavior in two species of calanoid copepods from nauplius to adult. J. Plankton Res. $35,49-65$.
Buskey, E.J., Lenz, P.H., Hartline, D.K., 2002. Escape behavior of planktonic copepods in response to hydrodynamic disturbances: high speed video analysis. Mar. Ecol. Prog. Ser. 19 (235), 135-146.

D’Agostino, V.C., Degrati, M., Sastre, V., Santinelli, N., Krock, B., Krohn, T., Dans, S.L., Hoffmeyer, M.S., 2017. Domoic acid in a marine pelagic food web: Exposure of southern right whales Eubalaena australis to domoic acid on the Península Valdés calving ground, Argentina. Harm. Algae 68, 248-257.

Eckert, R., Randall, E., 1983. Animal Physiology, 2nd ed. Freeman and Co., San Francisco.

Fields, D.M., Yen, J., 1997. The escape behavior of marine copepods in response to a quantifiable fluid mechanical disturbance. J. Plankton Res. 19, 1289-1304.

Fritz, L., Quilliam, M.A., Wright, J.L., Beale, A.M., Work, T.M., 1992. An outbreak of domoic acid poisoning attributed to the pennate diatom Pseudo-nitzschia australis 1. J. Phycol. 28 (4), 439-442.

Hansen, P.J., Bjornsen, P.K., Hansen, B.W., 1996. Zooplankton grazing and growth: scaling within the 2-2,000 $\mu \mathrm{m}$ body size range. Limnol. Oceanogr. 45 1891-1891.

Harðardóttir, S., Pancic, M., Tammilehto, A., Krock, B., Møller, E.F., Nielsen, T.G. Lundholm, N., 2015. Dangerous Relations in the Arctic Marine Food Web: Interactions between Toxin Producing Pseudo-nitzschia Diatoms and CalanusCopepodites. Mar. Drugs 13, 3809-3835.

Haury, L.R., Kenyon, D.E., Brooks, J.R., 1980. Experimental evaluation of the avoidance reaction of Calanus finmarchicus. J. Plankton Res. 2, 187-202.

Hirst, A.G., Kiørboe, T., 2002. Mortality of marine planktonic copepods: global rates and patterns. Mar. Ecol. Prog. Ser. 230, 195-209.

Jensen, S.K., Lacaze, J.P., Hermann, G., Kershaw, J., Brownlow, A., Turner, A., Hall, A., 2015. Detection and effects of harmful algal toxins in Scottish harbour seals and potential links to population decline. Toxicon 97, 1-14.

Kerfoot, W.C., 1978. Combat between predatory copepods and their prey: Cyclops, Epischura, and Bosmina. Limnol. Oceanogr. 23, 1089-1102.

Kiørboe, T., Visser, A.W., 1999. Predator and prey perception in copepods due to hydromechanical signals. Mar. Ecol. Prog. Ser. 179, 81-95.

Landsberg, J.H., 2002. The effects of harmful algal blooms on aquatic organisms. Rev. Fish. Sci. 10, 113-390.

Leandro, L.F., Teegarden, G.J., Roth, P.B., Wang, Z., Doucette, G.J., 2010a. The copepod Calanus finmarchicus: A potential vector for trophic transfer of the marine algal biotoxin, domoic acid. J. Exp. Mar. Biol. Ecol. 382, 88-95.

Leandro, L.F., Rolland, R.M., Roth, P.B., Lundholm, N., Wang, Z., Doucette, G.J., 2010b. Exposure of the North Atlantic right whale Eubalaena glacialis to the marine algal biotoxin, domoic acid. Mar. Ecol. Prog. Ser. 398, 287-303.

Madsen, S.D., Nielsen, T.G., Hansen, B.W., 2001. Annual population development and production by Calanus finmarchicus, C. glacialis and C. hyperboreusin Disko Bay, Western Greenland. Mar. Biol. 139, 75-93.

Maneiro, I., Iglesias, P., Guisande, C., Riveiro, I., Barreiro, A., Zervoudaki, S., Graneli, E., 2005. Fate of domoic acid ingested by the copepod Acartia clausi. Mar. Biol. 148, $123-130$.

McCullagh, P., 1984. Generalized linear models. Eur. J. Oper. Res. 16 (3), 285-292.

Miesner, A.K., Lundholm, N., Krock, B., Nielsen, T.G., 2016. The effect of Pseudo-nitzschia seriata on grazing and fecundity of Calanus finmarchicus and Calanus glacialis. J. Plankton Res. 38, 564-574.

Mullin, M.M., 1963. Some factors affecting the feeding of marine copepods of the genus Calanus. Limnol. Oceanogr. 8 (2), 239-250.

Ohman, M.D., 1988. Behavioral responses of zooplankton to predation. Bull. Mar. Sci. 43, $530-550$.

Quilliam, M.A., Wright, J.L.C., 1989. The amnesic shellfish poisoning mystery. Anal. Chem. 61, 1053-1060.

R Core Team, 2018. R: A Language and Environment for Statistical Computing. R Foundation for Statistical Computing, Vienna, Austria URL.

SigmaPlot version 13.0, Systat Software, Inc., San Jose California USA.

Swalethorp, R., Kjellerup, S., Dünweber, M., Nielsen, T.G., Møller, E.F., Rysgaard, S., Hansen, B.W., 2011. Grazing, egg production, and biochemical evidence of differences in the life strategies of Calanus finmarchicus, C. glacialis and C. hyperboreusin Disko Bay, western Greenland. Mar. Ecol. Prog. Ser. 429, 125-144.

Tammilehto, A., Nielsen, T.G., Krock, B., Møller, E.F., Lundholm, N., 2012. Calanus spp. vectors for the biotoxin, domoic acid, in the Arctic marine ecosystem? Harm. Algae 20, 165-174.

Tammilehto, A., Nielsen, T.G., Krock, B., Møller, E.F., Lundholm, N., 2015. Induction of domoic acid production in the toxic diatom Pseudo-nitzschia seriata by calanoid copepods. Aquat. Toxicol. 159, 52-61.

Tester, P.A.P.Y., Douchette, G.J., 2001. Accumulation of Domoic Acid Activity in Copepods. Intergovernmental Oceanographic Commission of UNESCO, Paris.

Titelman, J., 2001. Swimming and escape behavior of copepod nauplii: implications for predator-prey interactions among copepods. Mar. Ecol. Prog. Ser. 213, 203-213.

van Someren Gréve, H., Almeda, R., Kiørboe, T., 2017. Motile behavior and predation risk in planktonic copepods. Limnol. Oceanogr. 62 (5), 1810-1824.

Venables, W.N., Ripley, B.D., 2002. Modern Applied Statistics With S, fourth edition. Springer, New York ISBN 0-387-95457-0.

Windust, A., 1992. The Responses of Bacteria, microalgae, and Zooplankton to the Diatom Nitzschia pungens f. Multiseries and Its Toxic Metabolite Domoic Acid. M.S. Thesis. Dalhousie University, Halifax, Canada.

Wohlrab, S., Iversen, M.H., John, U., 2010. A molecular and co-evolutionary context for grazer induced toxin production in Alexandrium tamarense. PLoS One 5, e15039.

Wright, J.L.C., Boyd, R.K., Freitas, A.D., Falk, M., Foxall, R.A., Jamieson, W.D., Pathak, V.P., 1989. Identification of domoic acid, a neuroexcitatory amino acid, in toxic mussels from eastern Prince Edward Island. Can. J. Chem. 67 (3), 481-490. 